\title{
Synovium Targeting Delivery of TNF $\alpha$ Blocker for Rheumatoid Arthritis Therapy - A Mini Review
}

\author{
Riyona Desvy Pratiwi ${ }^{1 *}$, Muhammad Novrizal Abdi Sahid ${ }^{2}$ \\ ${ }^{1}$ Research Centre for Biotechnology, Indonesian Institute of Sciences, Bogor, Indonesia. \\ ${ }^{2}$ Department of Pharmaceutical Chemistry, Faculty of Pharmacy, Universitas Gadjah Mada, Yogyakarta, Indonesia.
}

\begin{tabular}{l}
\hline ARTICLE INFO \\
\hline Article history: \\
Received on: $08 / 02 / 2018$ \\
Accepted on: 06/06/2018 \\
Available online: $31 / 10 / 2018$ \\
\\
\hline Key words: \\
rheumatoid arthritis, tumor \\
necrosis factor $\alpha$ blockers, \\
synovium, targeted delivery.
\end{tabular}

\begin{tabular}{l}
\hline ABSTRACT \\
Tumor necrosis factor $\alpha(\mathrm{TNF} \alpha)$ blockers are proven to be potential suppressing agents for rheumatoid arthritis. \\
Aside from showing significant effects in clinical treatment, they are also known as the top-selling biological agents. \\
However, several systemic side effects related to infection and cancer are shown after treatments with systemic TNF $\alpha$ \\
blockers. In order to reduce and overcome the side effects, a targeted delivery is then requested. Synovium or synovial \\
membrane is considered as a promising delivery target because TNF $\alpha$ is highly accumulated within it. The current \\
article reviews a number of strategies that might be applied in the synovium targeting delivery of TNF $\alpha$ blockers.
\end{tabular}

ABSTRAC' Aside from showing significant effects in clinical treatment, they are also known as the top-selling biological agents. article reviews a number of strategies that might be applied in the synovium targeting delivery of TNF $\alpha$ blockers.

\section{INTRODUCTION: RHEUMATOID ARTHRITIS, AN AUTOIMMUNE DISEASE ATTACKS JOINTS AND CARTILAGE}

Rheumatoid arthritis (RA) is an autoimmune disease characterized by chronic inflammation of synovial joints leading to cartilage destruction and bone erosion (Belluci et al., 2016; Chaudari et al., 2016). It is commonly found in small joints such as hand and wrist. It also attacks other parts of the body, such as pulmonary and cardiovascular systems. The main clinical features of RA are swollen joints and hand tenderness. At the most severe stage, the RA might cause disability and premature mortality (Aletaha et al., 2010; Mc. Innes and Schett, 2011).

The etiology of RA remains unclear. However, genelike HLA and environmental risk factors have been showed to contribute to the disease pathogenesis (Belluci et al., 2016). In 2016, Yarwood and colleagues reported more than 100 susceptible genetic loci involved in RA pathogenesis. Among

\section{${ }^{*}$ Corresponding Author}

Riyona Desvy Pratiwi, Research Centre for Biotechnology, Indonesian Institute of Sciences, Bogor, Indonesia.

E-mail: riyona.desvy.pratiwi@ lipi.go.id them, HLA II gene encoding HLA-DBR was discovered to have significant involvement in RA pathogenesis. Those genetic loci are considered to be the main actors in RA development-starting as early as several years before the clinical symptoms appear. In an inductive environment, the susceptible genetic loci actively trigger autoimmune reaction then take the hidden potential RA stage to a higher stage of disease with obvious clinical symptoms (Yarwood et al., 2016).

Environmental risk factors such as cigarette smoking, infection of microbes, early life exposures, and hygiene are reported to contribute to the RA development (Edward and Cooper, 2005; Liao et al., 2009). Cigarette smoking increases oxidative stress in the body and modifies a specific amino acid sequence on HLA-DBR1. Thus, it is related to positive anticitrullinated peptides antibodies (ACPAs)-RA instead of the negative ACPAs-RA (Chang et al., 2014).

Microbial infection is also suspected to provoke RA emergence. Porphyromonas gingivalis, mycoplasma, parvovirus, and cytomegalovirus have been detected in the synovium (synovial membrane) and synovia (synovial fluid) of patients with RA (Li et al., 2014).

On the other hand, the use of oral contraception 
suppresses the development of rheumatoid factor (RF), the first marker antibody that is known for RA. However, the protective effect of the oral contraception in RA progression is still uncertain (Liao et al., 2009). In the early years of its discovery, RF was only identified as an immunoglobulin $\mathrm{M}(\operatorname{IgM})$, but later on, the other isotypes of immunoglobulin, e.g., $\operatorname{IgA}$ and $\operatorname{IgE}$, were also considered as the RF (Herman et al., 1986 and Hermann et al., 1991).

\section{THE IMPORTANCE OF TNF $\alpha$ IN THE PATHOGENESIS OF RHEUMATOID ARTHRITIS}

Pathogenesis of RA is started with stimulation of either $B$ cell or T cell which is previously infected by an antigen, such as microbes present in synovial fluid (Robbins and Kumar, 1995). Therefore, the stimulated B cell produces an antibody such as IgG. In patients with RA, the IgG has lack of terminal galactose residues at the $\mathrm{Fc}$ region which is different with that of from patients with others chronic inflammation and healthy population (Roitt et al., 1988). It is caused by the variation enzyme $\beta-1,4-$ galactosyltransferase (GTase), an important factor for $\mathrm{IgG}$ galactosylation (Alavi and Axford, 1995). Subsequently, the RF binds to the RA typical-IgG to form immune complexes which are recognized as antigens inducing cytokines. Thus, RA is classified as an autoimmune disease (Robbins and Kumar, 1995).

The release of cytokines is regulated by macrophage-like synoviocytes (MLS), especially M1 macrophages. They secret cytokines such as TNF $\alpha$, IL-1, IL-13, and IL-23. Another type of the MLS, M2 macrophages, are indirectly involved in cytokines secretion, yet act in phagocytosis, angiogenesis, and wound repair (Kennedy et al., 2011; Laria et al., 2016). The patients with RA are more sensitive in TNF $\alpha$ and its p75 receptor release than in patients with other chronic inflammation such as osteoarthritis because TNF $\alpha$ converting enzyme (TACE) - the main regulator in $\mathrm{TNF} \alpha$ release is highly prevalent in that population only (Ohta et al., 2001).

Among numerous cytokines involved in the pathogenesis of RA, TNF $\alpha$ and IL-1 play the superior roles in the disease progression. $\mathrm{TNF} \alpha$ contributes to synovial inflammation, whereas IL-1 induces joints destruction (Toussirot and Wendling, 2004) (Figure 1). However, targeting TNF $\alpha$ in RA therapy is preferable to IL-1 because it allows the downregulation of other pro-inflammatory cytokines, including IL-1 (Feldman et al., 2002). In addition, the epitope of $\mathrm{TNF} \alpha$ is highly detected and localized in the synovial tissue of patients with RA, showing that TNF $\alpha$ is produced by active synovial lining cells (Husby et al., 1988). It is commonly found in synovial tissue and fluid of RA and not prevalent in osteoarthritis or systemic lupus (Matsuno et $a l ., 2002)$. From an in vitro study, it is known that TNF $\alpha$ was able to induce production of other cytokines e.g. IL-1 and IL-6. On contrary, IL-6 did not induce production of the TNF $\alpha$. Besides, in an in vivo study, TNF $\alpha$ showed the stronger effect to trigger synovial inflammation than IL-6 did (Matsuno et al., 2002).

$\mathrm{TNF} \alpha$ independently induces inflammation in RA even in the absence of other pivotal cytokines, like IL-1, but not contrariwise. However, it does not directly influence joint destruction and bone erosion-the clinical manifestation of RA (Matsuno et al., 2002). TNF $\alpha$ provokes the production of IL-1 in the synoviocytes and subsequently induces the synthesis of matrix metalloproteinases (MMPs) in chondrocytes and fibroblasts. These enzymes degrade extracellular components, such as collagens, proteoglycans, and hyaluronic acids, causing the cartilage to lose its movement and pressure protection-leading to joint damage and bone erosion (Burrage et al., 2006). In a preclinical study, the number of synovial inflammation cells in an RA-induced mouse dwindled after receiving TNF $\alpha$ blocker treatment. Furthermore, the treatment also managed to control the level of IL- 6 in the mouse serum, though not contrarily. Thus, TNF $\alpha$ blocking is a potential strategy in RA therapy (Matsuno et al., 2002).

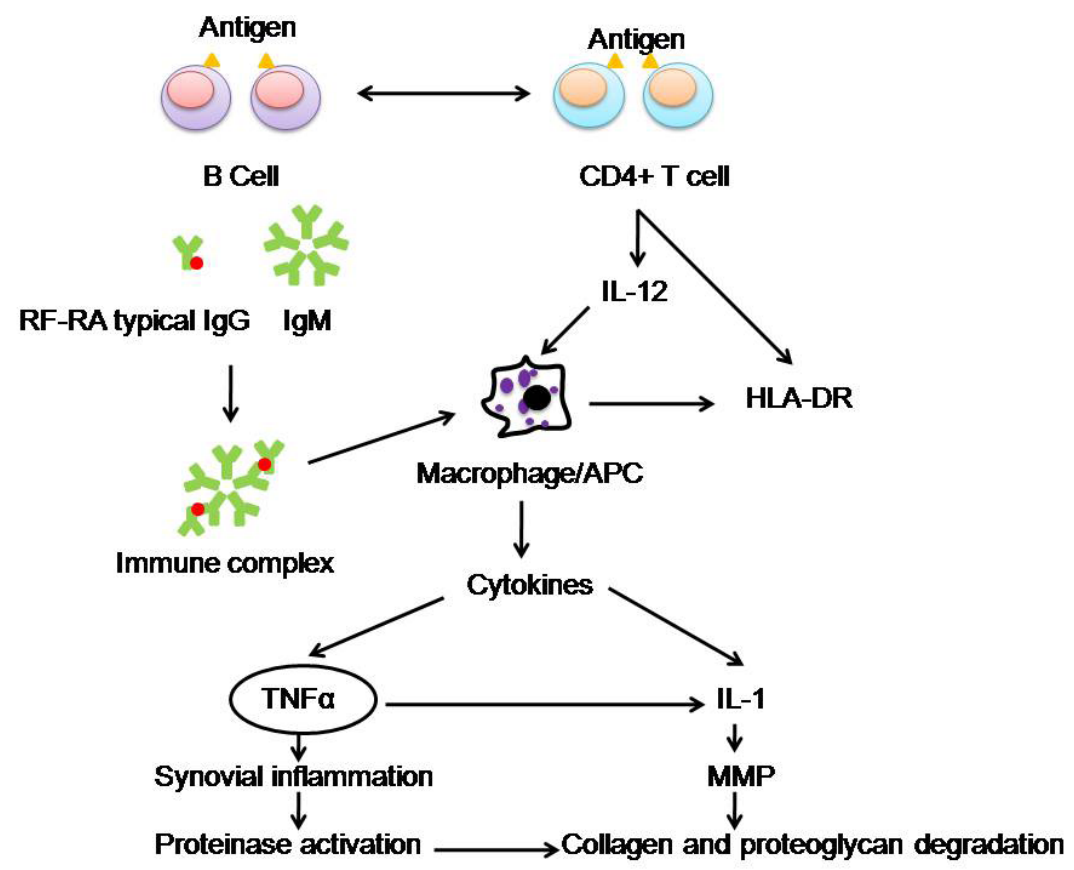

Fig. 1: Pathogenesis of rheumatoid arthritis. TNF $\alpha$ plays an important role in synovial inflammation (Robbins and Kumar, 1995; Toussirot and Wendling, 2004). 


\section{TNF $\alpha$ BLOCKERS: BIOLOGICAL DRUG OF CHOICE FOR RHEUMATOID ARTHRITIS}

Various types of TNF $\alpha$ blockers have been available on the market worldwide and commonly used in clinical therapy for RA (Table 1). TNF $\alpha$ blocker as a biological drug is recommended for patients with moderate and severe RA when DMARD (disease modifying anti-rheumatoid drugs) like methotrexate is not effective (Singh et al., 2015). TNFa blockers have been developed in two subclasses. The first subclass is an anti-TNF $\alpha$ antibody that neutralizes $\mathrm{TNF} \alpha$, while the second subclass acts as $\mathrm{TNF} \alpha$ soluble receptor to prevent TNF $\alpha$ from binding with its cell surface receptor (Salfeld and Kaymakcalan, 1998; Taylor et al., 2009; Moelants, et al., 2013).

Table 1. List of approved TNF $\alpha$ blockers (Krzysztof et al., 2014; Knight, 1993; Kempeni, 2000; Mittal and Raychaudhuri, 2010; Marotte and Cimaz, 2014).

\begin{tabular}{|c|c|c|c|c|}
\hline Name & Molecule & $\begin{array}{c}\text { Date of } \\
\text { approval }\end{array}$ & Developer & $\begin{array}{c}\text { Marketing Authorization } \\
\text { Holder }\end{array}$ \\
\hline Infliximab (Remicade ${ }^{\circledR}$ ) & Murine Fab-human Fc & $\begin{array}{l}\text { FDA - } 1998 \\
\text { EMA - } 1999\end{array}$ & Centocor Schering - Plough & Janssen Biologics B.V. \\
\hline Adalimumab (Humira ${ }^{\circledR}$ ) & Human Fab-human Fc & $\begin{array}{l}\text { FDA - } 2005 \\
\text { EMA - } 2003\end{array}$ & Abbott & AbbVie Ltd. \\
\hline Golimumab (Simponi $\left.{ }^{\circledR}\right)$ & Human Fab- human Fc & $\begin{array}{l}\text { FDA - } 2009 \\
\text { EMA - } 2009\end{array}$ & Centocor Schering - Plough & Janssen Biologics B.V. \\
\hline Etanercept (Enbrel $\left.{ }^{\circledR}\right)$ & The extracellular domain of human soluble TNFR - human Fc & $\begin{array}{l}\text { FDA - } 1998 \\
\text { EMA - } 2000\end{array}$ & Amgen, Wyeth, Takeda & Pfizer Ltd. \\
\hline
\end{tabular}

Infliximab, which was previously named A2 antibody (cA2), is the pioneer of TNF $\alpha$ blocker approved as a biological drug for RA (Taylor et al., 2009). It is a chimeric anti-TNF $\alpha$ antibody containing murine antigen binding fragment (Fab) and human constant fragment $(\mathrm{Fc})$. In the early days of its development, infliximab had shown a specific affinity to human TNF $\alpha$. It neither binds to lymphotoxin (TNFb) nor TNF $\alpha$ from other species (except small binding to chimpanzee`s $\mathrm{TNF} \alpha$ ) (Knight et al., 1993). Infliximab was launched in the market in 1998 with the brand name of Remicade $\AA$. The next anti-TNF $\alpha$ antibody, named D2E7 or adalimumab, is also developed as a monoclonal antibody. However, the murine Fab region was substituted with human's, and therefore, claimed to be less immunogenic (Salfeld and Kaymakcalan, 1998; Kempeni, 2000). This antibody is marketed as Humira ${ }^{\circledR}$ and is leading in terms of sales among anti-TNF $\alpha$ antibodies (Lybecker, 2012). The presence of adalimumab is followed by CNTO148 (Golimumab, Simponi ${ }^{\circledR}$ ). Both have a similar half-time (14 days), but golimumab is prepared for once per month dosage, whereas adalimumab needs a more frequent administration that is twice per month (Mittal and Raychaudhuri, 2010).

The second subclass of TNF $\alpha$ blocker is represented by etanercept. Unlike infliximab and other anti-TNF $\alpha$ antibodies, etanercept is designed as the fusion of two extracellular domains - human soluble p75 TNF receptor and the Fc of human IgG1 (Marotte and Cimaz, 2014). The development of etanercept was initiated by a study on the fusion of extracellular domains, namely p55 TNF receptor and the Fc of murine IgG1 performed by Peppel and colleagues (Peppel et al., 1991). Etanercept mimics the mechanism of soluble TNF receptor to bind the TNF $\alpha$ prior to interacting with $\mathrm{TNF} \alpha$ receptors on the cell surface. Therefore, it only binds to the soluble TNF $\alpha$, not targeting the receptor bound-TNF $\alpha$. Up to now, etanercept is the only TNF $\alpha$ blocker in the second subclass and has been marketed since 1998 under the product name of Enbrel ${ }^{\circledR}$ (Krzyztof et al., 2014). TNF $\alpha$ blockers achieved over 15 billion USD in sales in 2014, giving it the title of top-selling RA medicine, with other biological drugs and DMARDs following behind (Chaudari et al., 2016). Apart from the above-mentioned product names of TNF $\alpha$ blocker, Humira ${ }^{\circledR}$,
Enbrel $\AA$, and Remicade $\AA$ have become top-selling biological drugs for years (Lawrence and Lehteenmaki, 2013; Lybecker, 2016).

Even though TNFa blockers have shown lots of advantages in RA therapy, some shortcomings are causing problems. The ones available thus far are only for systemic effects and used via intravenous or subcutaneous injection. This leads to several adverse effects related to the natural immune condition. Long-term use of TNF $\alpha$ blockers has the potential to cause lymphoma, infections, and other diseases related to the immune system (Scheinfeld, 2004; Bongartz et al., 2006).

At the beginning of its discovery, TNF $\alpha$ was found as a necrotic cytokine secreted by macrophages against tumor cells (Carswell et al., 1975). Later on, it was found that TNF $\alpha$ plays pivotal roles in the regulation of cell differentiation, proliferation, and death (Wang and Lin, 2008). In regards to cell death, TNF $\alpha$ stimulates TNFR1 to recruit TNF $\alpha$ receptor-associated death domain (TRADD), Fas-associated death domain (FADD) and Caspase 8 or FADD-like ICE (FLICE) resulting pro-apoptotic and anti-apoptotic proteins that regulate membrane outer mitochondrial permeabilization (MOMP). As a consequence, cytochrome-c is released from mitochondria and activates caspase-3, which leads to apoptosis. Therefore, interference of TNF $\alpha$ 's role in cell death triggers uncontrolled cell growth closely associated with cancer (Elmore, 2007; Sethi, 2008; Tait and Green, 2013).

It is reported that $\mathrm{TNF} \alpha$ blockers contribute specifically to lymphoma cancers (even though the correlation was weak) instead of the non-lymphoma ones (Scheinfeld, 2004). In another study, it is suggested that there is no significant difference between the lymphoma risk of patients treated with TNF $\alpha$ blockers and those receiving non-biological DMARDs. However, patients who had suffered from lymphoma should avoid TNF $\alpha$ blockers since it could increase the risk of recurrence (Jain and Singh, 2013).

$\mathrm{TNF} \alpha$ is an imperative cytokine in suppressing microbial infections (Rahman and McFadden, 2006). Therefore, inhibiting TNF $\alpha$ using an immunosuppressant such as TNF $\alpha$ blocker increases the risk of infection by two-fold in patients with RA (Listing et al., 2013). It is also reported that TNF $\alpha$ blockers induce some instances of bacterial infections: Mycobacterium tuberculosis, 
Streptococcus pneumoniae and Listeria monocytogenes; fungal infections: Pneumocystis jirrovecii, Aspergillus fumigates, Cryptococcus neoformans and Histoplasma capsulatum; and viral infections: hepatitis B virus (HBV) and hepatitis C virus (HCV) (Ellerin et al., 2003; Murdaca et al., 2015). Nevertheless, infection in patients with RA is not solely caused by TNFa blockers administration. Other causes of infection are the comorbidity of the RA itself, a combination of TNF $\alpha$ blockers with DMARDs or glucocorticoids (GCs), and chronic infection related medical history. In addition, infection susceptibility is higher in elderly patients (Listing et al., 2013). Whereas the risk of serious infection in patients increases upon receiving standard or a higher dose of biological drugs, the risk of serious infection in patients receiving TNF $\alpha$ blockers increases when the dosage is low (Singh et al., 2015).

Based on the above-mentioned issues, targeted delivery of TNF $\alpha$ blockers is then considered. As TNF $\alpha$ is accumulated in inflamed synovial tissue, targeting that very tissue would be an effective strategy which can be applied by conjugating a synovial targeting agent with a TNF $\alpha$ blocker (Garrood and Pitzallis, 2006).

\section{DEVELOPMENTOFSYNOVIUMTARGETINGAGENTS FOR TNF $\alpha$ BLOCKERS}

Synovial tissue is a membrane which lines the inner parts of the synovial joint. It houses articular cartilage and joint cavity and filled with synovial fluid (Barland et al., 1962). The membrane is composed of two layers: the intima and subintima layers. Intima layer, which is found in the surface of the tissue, consists of two types of cells, namely the macrophage-like synoviocytes (MLS) or type A synoviocytes and fibroblast-like synoviocytes (FLS) or type B synoviocytes (Figure 2). This layer provides extracellular matrix molecules to regulate the production and clearance of synovial fluid. Subintima layer, the one below intima, is formed by adipocytes, fibroblasts, macrophages, mast cells, elastin, and blood vessels. Subintima layer has components with fibrous, areolar, and adipose morphology (Tiwari, 2010). In patients with RA, synovial tissue has characteristics distinguishable from that of a healthy population. Hence, the characteristics of synovial tissue found in patients with RA are valuable to determine the appropriate RA therapy. In the synovial tissue of patients with RA, the proliferation of intima layer is detected, along with lymphocytes and plasma cells infiltration as well as increased vascularity and fibrosis (Bartok and Firestein, 2010).

To our knowledge, TNF $\alpha$ blockers have not been conjugated or fused with any synovial targeting agents yet. However, a number of studies have been carried out to develop the targeting agents, such as homing peptide for other antiinflammatory drugs and other biological products for RA therapy (Mi et al., 2003; Yang et al., 2011; Wythe et al., 2013). In addition, the discovery of RA biomarkers might be useful in developing anti-biomarkers which can also be used as targeting agents (Bao et al., 2009).

\section{Synthetic peptides for synovium targeting}

Several synthetic homing peptides have been identified and showed specificity to synovium or synovial membrane and to endothelial cells in the synovial membrane. Therefore, they are suggested to be coupled with TNF $\alpha$ blockers for synovium targeting delivery thereof.

Mi et al. (2003) successfully screened two synovial homing peptides, HAP-1 (SFHQFARATLAS) and HAP-2 (HIQLSPFSQSWR) from an M13 phage library. Those peptides facilitated internalization of large protein into HIG-82-a synovium cell line, but HAP-1 was more effective than HAP-2.

Yang et al. (2011) identified targeting peptides, ADK (CRNADKFPC) and NQR (CLDNQRPKC) which was specific for endothelial cells in the inflamed synovial membranes. The accumulation of those peptides was higher in the inflamed synovial membrane than in other inflamed tissues, like skin or normal tissues.

Wythe et al. (2013) synthesized synovium targeting peptide, namely SyETP (CKSTHDRLC) and fused it with an anti-inflammatory cytokine: IL-4. In the study, the fusion of SyETP-IL4 was injected into a human synovial tissue transplanted mouse. The SyETP increased the accumulation of IL-4 in the synovial tissue and prolonged the half-life $\left(\mathrm{t}^{1 /} / 2\right)$ of the IL4, making it approximately twice as long compared to free IL-4. The biological activity of the fusion was represented as the level of STAT6 phosphorylation in the synovial tissue that activated by IL-4 (Wythe et al., 2013). Colombo et al. (2016) reported a synovial membrane targeting delivery system called $\mathrm{MC13}$, in which a synthetic peptide (CKSTHDRLC) was attached to Fab of adalimumab. The system was effective to neutralize TNF $\alpha$ in an in vitro study, selective at the inflamed synovial membrane and showed no toxic effects in an in vivo study.

\section{Rheumatoid arthritis biomarkers to target the synovium}

In addition to targeting peptides design, biomarkers discovery in RA pathogenesis also promotes the development of synovial targeting agent. Expression of podoplanin (PDPN) and CD248 or endosialin have been detected on TGF-1b, TNF $\alpha$ and IL-1b induced synovial fibroblasts or fibroblast-like synoviocytes (FLS), a population of synovial cells responding collectively with extracellular matrix and collagen. Both PDPN and CD248 are found in normal tissue (Croft et al., 2016). PDPN is mainly found in intima layers of the synovial membrane, while the CD248 is found in both intima and subintima layers (Croft et al., 2016; Hardy et al., 2013) (Figure 2). The allocation of those proteins is controlled by the FLS themselves without any interferences from other immune cells or stimulus (Lee et al., 2007). In regards to RA pathogenesis, PDPN plays a more important role than CD248 because the intima layers undergo hyperplasia, invade cartilage and bone, and ultimately cause cartilage damage and bone erosion (Ekwall et al., 2011). Therefore, it is suggested that PDPN might be beneficial as RA target therapy. On one hand, an anti-PDPN is considered in PDPN neutralization, but on the other hand, it can be fused with other RA therapy agents, such TNF $\alpha$ blocker, for the sake of a specific delivery.

Visfatin, another RA biomarker, is also demonstrated as a potential therapeutic target. Visfatin or pro-B cell colonyenhancing factor (PBEF) or nicotinamide phosphoribosyl transferase (Nampt) is a $52 \mathrm{kDa}$ protein secreted by adipose, synovial, and cartilage tissue as well as peripheral blood mononuclear cells (Laiguillon et al., 2014) (Figure 2). In mouse models and patients with RA, serum and synovial tissue level of visfatin were found to be significantly higher than in normal 
population (Busso et al., 2008; Mirfeizi et al., 2014; Lee et al., 2017). It induced secretion of pro-inflammatory cytokines and assumed to be facilitating joint damage via MMP secretion (Bao et al., 2009). Therefore, visfatin is considered as a potential target for RA therapy (Mirfeizi et al., 2014). Similar with PDPN, an anti-visfatin can be used to neutralize the level of visfatin or as a targeting agent to deliver other anti-RA drugs to the synovial tissue, like TNF $\alpha$ blocker. Surprisingly, administration of TNF $\alpha$ blocker, namely infliximab, did not suppress the serum level of visfatin in a clinical study (Gonzalez et al., 2010). The effect of the anti-RA drug on visfatin level in the synovial tissue needs more investigation. Moreover, finding out the capacity of visfatin in the synovial tissue so as to accumulate anti-visfatin or other RA drugs in the local joint still requires more studies (Bao et al., 2009).

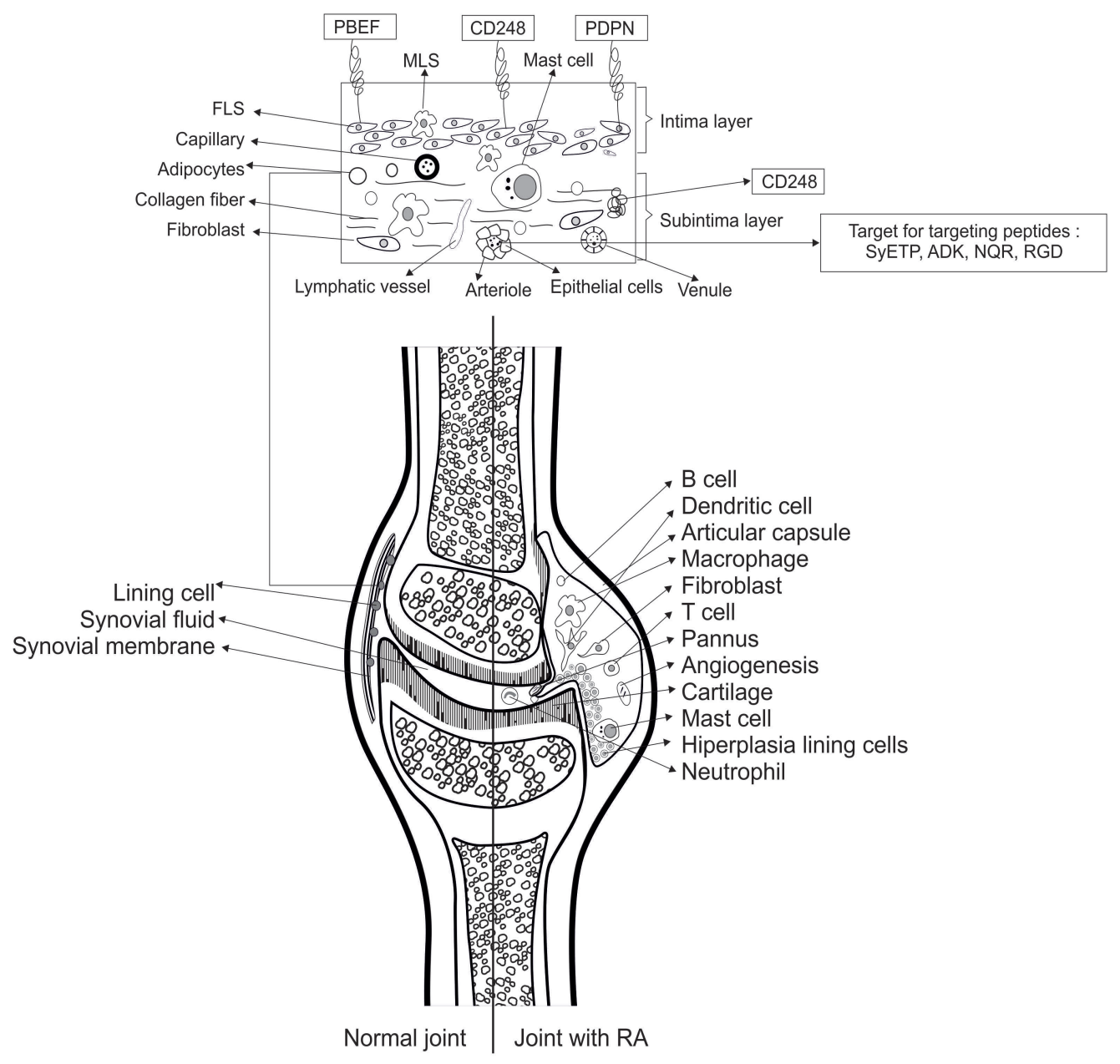

Fig. 2: Structure of normal joint and a joint with rheumatoid arthritis (RA). In the magnified synovial membrane: RA specific biomarkers, such as PBEF and PDPN are found in the fibroblast like-synoviocytes, and CD248 is found both in intima and subintima layer. The synthetic targeting peptides are designed to target epithelial cells in the subintima layer (Brentano et al., 2007; Croft et al., 2016; Hardy et al., 2013; Meier et al., 2012).

\section{Conclusion and future perspective}

$\mathrm{TNF} \alpha$ blockers are known as strong inhibitors for inflammation diseases, like RA, but they might cause a systematic side effect. The systematic side effect of TNF $\alpha$ blockers can be reduced by specific delivery to a certain target. In regards to the application of TNF $\alpha$ in RA therapy, synovial membrane is considered as a potential target because TNF $\alpha$ and its receptor are highly found therein

From the previous studies, a number of synthetic synovium homing peptides were reported. They were coupled with any compounds to direct them to the synovial membrane. HAP-1 and HAP-2 facilitated internalization of large proteins to the synovial membrane, whereas ADK, NQR, dan SyETP were used as targeting agents to the endothelial cells in the synovial membrane. According to those reports, the synovium homing peptides are suggested to be coupled with $\mathrm{TNF} \alpha$ blockers, so they are able to be specifically delivered to the inflamed synovial membrane. 
In addition, an anti-RA biomarker, for instance, antipodoplanin, anti-endosialin, and anti-visfatin are also potential to be coupled with TNF $\alpha$ blockers because they have been known as specific RA biomarkers which are accumulated in the inflamed synovial membrane. However, advanced studies still need to be carried out in order to confirm the effectivity and selectivity of these strategies for specific delivery of TNF $\alpha$ blockers.

As previously mentioned, the more potential a drug, the higher the tendency of side effects occurrence. Nonetheless, to take optimal benefits of the drug, a specific delivery is needed. In this case, $\mathrm{TNF} \alpha$ blockers which are the most used and potential drug for RA therapy are suggested to be coupled with the reviewed agents to the obtained specific accumulation of them in the damaged tissue such as a synovial membrane.

\section{CONFLICT OF INTEREST}

The authors have no conflict of interest.

\section{LIST OF ABBREVIATION}

ACPAs: anticitrullinated peptides antibodies

DMARD: disease-modifying anti-rheumatoid drugs

Fab: antigen binding fragment

FADD: Fas-associated protein with death domain

Fc: constant fragment

FLICE: FADD-like IL-1 $\beta$-converting enzyme

FLS: fibroblast-like synoviocytes

GCs: glucocorticoids

GTase: beta 1,4-Galactosyltransferase

HBV: hepatitis B virus

$\mathrm{HCV}$ : hepatitis $\mathrm{C}$ virus

HLA: human leukocyte antigen

Ig: immunoglobulin

IL: interleukin

MLS: macrophage-like synoviocytes

MOMP: membrane outer mitochondria permeabilization

MMP: matrix metalloproteinase

PBEF: pro-B cell colony enhancing factor

RA: rheumatoid arthritis

RANKL: Receptor activator of nuclear factor kappa-B ligand

RF: rheumatoid factor

TACE: TNF $\alpha$ converting enzyme

TNF $\alpha$ : tumor necrosis factor $\alpha$

TRADD: TNFR1-associated death domain protein

\section{REFERENCES}

Alavi A, Axford J. Evaluation of beta 1,4-galactosyltransferase in rheumatoid arthritis and its role in the glycosilation network associated with this disease. Glycoconj J, 1995; 12(3):206-210.

Aletaha D, Neogi T, Silman AJ, et al. Rheumatoid arthritis classification criteria, An American College of Rheumatology/European League against rheumatism. Arthritis \& Rheumatism, 2010; 62(9):25692581.

Barland P, Novikoff AB, Hamerman D. Electron microscopy of the human synovial membrane. J Cell Bio, 1962; 14(2):207-220.

Bartok B, Firestein GS. Fibroblast-like synoviocytes: key effector cells in rheumatoid arthritis. Immunol Rev, 2010; 233(1):233-255.

Bao JP, Chen WP, WuL D. Visfatin: a potential therapeutic target for rheumatoid arthritis. J Int Med Res, 2009; 37(6):1655-1661.

Belluci E, Terenzi R, La Paglia GMC, et al. One year in review 2016: pathogenesis of the rheumatoid arthritis. Clin Exp of Rheum, 2016; 34:793-801.
Bongartz T, Sutton AJ, Sweeting MJ et al., Anti-TNF antibody therapy in rheumatoid arthritis and the risk of serious infections and malignancies: Systematic review and meta-analysis of rare harmful effects in randomized controlled trials. JAMA, 2006; 295(19):2275-2285.

Brentano F, Schorr O, Ospelt C et al. Pre-B cell colony enhancing factor/visfatin, a new marker of inflammation in rheumatoid arthritis with proinflammatory and matrix-degrading activities. Arthritis \& Rheumatism, 2007; 56(9):2829-2939.

Burrage PS, Mix KS, Brinckerhoff CE. Matrix metalloproteinanses: role in arthritis. Front Biosci, 2006; 1:529-543.

Busso N, Karababa M, Nobile M, et al. Pharmacological inhibition of nicotinamide phosphoribosyl transferase/visfatin enzymatic activity identifies a new inflammatory pathway linked to NAD. PLoS One, 2008; 3(5):e2267.

Carswell EA, Old LJ, Kassel RL, et al. An endotoxin-induced serum factor that causes necrosis of tumors (activated macrophage). Proc Nat Acad Sci USA, 1975; 72(9):3666-3670.

Chang K, Yang SM, Kim SH, et al. Smoking and Rheumatoid Arthritis. IJMS, 2014; 15(12):22279-22295.

Chaudari K, Rizvi S, Syed BA, et al. From the analyst's couch, Rheumatoid arthritis: current and future trends. Nat Rev Drug Discovery, $2016 ; 15: 1-2$.

Colombo F, Sblattero D, De Maso L, et al. 2016. Anti-TNFa antibody targeted to inflamed synovial tissue for the treatment of rheumatoid arthritis. Conference Paper in Annals of the Rheumatic Diseases [ONLINE] Available at http://ard.bmj.com/content/75/Suppl_2/436.2 [Accessed 07 May 2018]

Croft AP, Naylor AJ, Marshall JL et al. Rheumatoid synovial fibroblast differentiate into distinct subsets in the presence of cytokines and cartilage. Arthritis Res Ther, 2016; 18:1-11.

Edwards CJ, Cooper C. Early environmental factors and rheumatoid arthritis.Clin Exp Immun, 2005; 143:1-5.

Ekwall AKH, Eisler T, Anderberg C, et al. The tumour-associated glycoprotein podoplanin is expressed in fibroblast-like synoviocytes of hyperplastic synovial lining layer in rheumatoid arthritis. Arthritis Res Ther, 2011; 13(2):R40.

Ellerin T, Rubin RH, Weinblatt ME. Infections and anti-tumor necrosis factor therapy. Arthritis Rheum, 2003; 48(11):3013-3022.

Elmore S. Apoptosis: A review of programmed cell death. Toxicol Pathol, 2007; 35(4):494-516.

Feldmann M, Brennan FM, Maini RN. Role of cytokines in rheumatoid arthritis. Annu Rev Immunol, 1996; 14:397-440.

Garrood T, Pitzalis C. Targeting the inflammed synovium: The quest for specificity. Arthritis Rheum, 2006; 54(4):1055-1060.

Gonzalez-Gay MA, Vazquez-Rodriguez TR, Garcia-Unzueta MT, et al. Visfatin is not associated with inflammation or metabolic syndrome in patients with severe rheumatoid arthritis undergoing antiTNF-alpha therapy. Clin Exp Rheumatol, 2010; 28(1):56-62.

Hardy RS, Hulso C, Lui Y et al. Characterisation of fibroblastlike synoviocytes from a murine model of joint inflammation. Arthritis Res Ther, 2013; 15(1):R24.

Herman E, Vogt P, Müller W. Rheumatoid Rheumatoid factors of immunoglobulin classes $\operatorname{IgA}, \operatorname{IgG}$ and $\operatorname{IgM}$ : Methods of determination and clinical value. Schweizerischemedizinische Wochenschrift, 1986; 116 (38):1290-1297.

Herrmann D, Jäger L, Hein G, et al. IgE rheumatoid factor Occurrence and diagnostic importance in comparison with IgM rheumatoid factor and circulating immune complexes. J Investig Allergol ClinImmunol, 1991; 1(5):302-307.

Husby G, Williams RC Jr. Synovial localization of tumor necrosis factor in patients with rheumatoid arthritis. J. Autoimmune, 1988; 1(4):363-371.

Jain A, Singh JA. Harms of TNF inhibitors in rheumatic diseases: a focused review of the literature. Immunother, 2013; 5(3):265-299.

Kempeni J. Update on D2E7: a fully human anti-tumour necrosis factor $\alpha$ monoclonal antibody. Ann Rheum Dis, 2000; 59(suppl I): i44-i45. 
Kennedy A, Fearon U, Veale DJ et al. Macrophages in synovial inflammation. Front Immunol, 2011; 10(2):1-9.

Knight DM, Trinh H, Le J et al. Construction and initial characterization of a mouse-human chimeric anti-TNF antibody. Mol Immunol, 1993; 30(16): 1443-1453.

Krzysztof L, Kuzawinska O, Iskra EB. Tumor necrosis factor inhibitors - state of knowledge. Arch Med Sci, 2013; 10(6):1175-1185.

Laria A, Lurati A, Marrazza M, et al. The macrophages in rheumatic diseases. J Inflamm Res, 2016; 9:1-11.

Laiguillon MC, Houard X, Bougault $\mathrm{C}$ et al. Expression and function of visfatin (Nampt), an adipokine-enzyme involved in inflammatory pathways of osteoarthritis. Arthritis Res Ther, 2014; 16(1) R38.

Lawrence S, Lahteenmaki R. Public biotech 2013 - the numbers. Nat Biotech, 2014; 32(7):626-632.

Lee DM, Kiener HP, Agarwal SK et al. Cadherin-11 in synovial lining formation and pathology in arthritis. Science, 2007; 315:1006-1010.

Lee YH, Bae SC. Circulating adiponectin and visfatin levels in rheumatoid arthritis and their correlation with disease activity: A metaanalysis. Int J Rheum Dis, 2017: doi:10.1111/1756-185X.13038.

Li S, Yu Y, Yue Y et al. Microbial infection and rheumatoid arthritis. J Clin Cell Immun, 2014; 4(6): doi.10.4172/2155-9899.1000174.

Liao KP, Alfredsson L, Karlsona EW. Environmental influences on risk for rheumatoid arthritis. Curr Op Rheum, 2009; 21(3): 279-283.

Listing J, Gerhold K, Zink A. The risk of infections associated with rheumatoid arthritis, with its comorbidity and treatment. Rheumatology, 2013; 52:53-61.

Lybecker K. 2016. The Biologics Revolution in the Production of Drugs. [ONLINE] Available at: https://www.fraserinstitute.org/studies/ biologics-revolution-in-the-production-of-drugs [Accessed 09 May 2018].

Marotte H, Cimaz R. Etanercept - TNF receptor and IgG1 Fc fusion protein: is it different from other TNF blockers?. Expert Opin Biol Ther, 2014; 14(5):569-572.

Matsuno H, Yudoh K, Katayama $\mathrm{R}$ et al. The role of TNFalpha in the pathogenesis of inflammation and joints destruction in rheumatoid arthritis (RA): a study using human RA/SCID mouse chimera. Rheumatology, 2002; 41(3):329-337.

McInnes IB, Schett G. Mechanism of Disease The Pathogenesis of Rheumatoid Arthritis. The New England Journal of Medicine, 2011; 8:2205-2219.

Meier FM, Frommer KW, Peters MA, et al. Visfatin/pre-B-cell colony-enhancing factor (PBEF), a proinflammatory and cell motilitychanging factor in rheumatoid arthritis. J Biol Chem, 2012; 287(34):2837828385 .

Mi Z, Lu X, Mai JC et al. Identification of a synovial fibroblastspecific protein transduction domain for delivery of apoptotic agents to hyperplastic synovium. Mol Ther, 2003; 8(2):297-305.

Mirfeizi Z, Noubakht Z, Rezaie AE et al. Plasma levels of leptin and visfatin in rheumatoid arthritis patients: is there any relationship with joint damage?. Iran J Basic Med Sci, 2014; 17(9):662-666.

Mittal M, Raychaudhuri SP. Golimumab and certolizumab: The two new anti-tumor necrosis factor kids on the block. Indian J Dermatol Venereol Leprol, 2010; 76(6):602-609.

Moelants EAV, Mortier A, Damme JV et al. Regulation of TNF-a with a focus on rheumatoid arthritis. Immun Cell Bio, 2013; 91(6):393-401.

Murdaca G, Spano F, Contatore $\mathrm{M}$ et al. Infection risk associated with anti-TNF $\alpha$ agents: a Review. Expert Opinion Drug Safe, 2015; 14(4):112.
Ohta S, Harigai M, Tanaka M et al. Tumor necrosis factor-alpha (TNF-alpha) converting enzyme contributes to production of TNF-alpha in synovial tissues from patients with rheumatoid arthritis. J Rheumatol, 2001; 28(8):1756-1763.

Peppel K, Crawford D, Beutler B. A tumor necrosis factor (TNF) receptor IgG heavy chain chimeric protein as a bivalent antagonist of TNF activity. J Exp Med, 1991; 174:1483-1489.

Rahman MM, McFadden G. Modulation of tumor necrosis factor by microbial pathogens. PLoS Pathogens, 2006; 2(2):e4.

Robbins SL, Kumar V. 1995. Buku Ajar Patologi I diterjemahkan oleh Staf Pengajar : Laboratoriumpatologi Anatomik Fakultas Kedokteran Universitas Airlangga. Jakarta, Indonesia: Penerbit Buku Kedokteran EGC.

Roitt IM, Dwek RA, Parekh RB et al. The role of antigen in autoimmune responses with special reference to changes in carbohydrate structure of IgG in rheumatoid arthritis. J Autoimmun, 1988; 1:499-506.

Salfeld J, Kaymakcalan, Z. Generation of fully human anti-TNF antibody D2E7. Arthritis \& Rheumatism, 1998; 41(9):S57.

Scheinfeld N. A comprehensive review and evaluation of the side effects of the tumor necrosis factor alpha blockers etanercept, infliximab, and adalimumab. J Dermatolog Treat, 2004; 15(5):280-294.

Sethi G, Sung B, Aggarwal BB. TNF: A master switch for inflammation to cancer. Frontiers in Bioscience, 2008; 13(13):5094-5107.

Singh JA, Saag KG, Jr. Bridges L et al. American College of Rheumatology Guideline for the Treatment of Rheumatoid Arthritis. Arthritis Care \& Research, 2015: doi10.1002/acr.22783.

Tait SWG, Green DR. Mitochondrial regulation of cell death. Cold Spring Harb Perspect Biol, 2013; 5:a008706.

Taylor PC, Feldmann M. Anti-TNF biologic agents: still the therapy of choice for rheumatoid arthritis. Nature Reviews Rheumatology, 2009; 5:578-582.

Tiwari N. Imaging of normal and pathologic joint synovium using non-linear optical microscopy as a potential diagnostic tool. J Biomed Opt, 2010; 15(5):056001.

Toussirot E, Wendling D. The use of TNF blocking agents in rheumatoid arthritis: an overview. Expert Opinion on Pharmacotherapy, 2004; 5(3):581-594.

Wang X, Lin Y. Tumor necrosis factor and cancer, buddies or foes?. Acta Pharmacol Sin, 2008; 29(11):1275-1288.

Wythe SE, DiCara D, El Tahar T et al. Targeted delivery of cytokine therapy to rheumatoid tissue by a synovial targeting peptide. Ann Rheum Dis, 2013; 72(1):129-135.

Yang YH, Rajaiah R, Rouslahti E et al. Peptides targeting inflamed synovial vasculature attenuate autoimmune arthritis. Proc Natl Acad Sci USA, 2011; 108(31):12857-12862.

Yarwood A, Huizinga TWJ, Worthington J. RA: from risk factors and pathogenesis to prevention: The genetics of rheumatoid arthritis: risk and protection in different stages of the evolution of RA. Rheum, 2016; 55:199-209.

How to cite this article: Pratiwi RD, Sahid MNA. Synovium Targeting Delivery of TNF $\alpha$ Blocker for Rheumatoid Arthritis Therapy - A Mini Review. J App Pharm Sci, 2018; 8(10): 165-171. 